\title{
Yazar Cinsiyetini Sezgisel Düzeyde Ortaya Çıkaran Dilsel Birimler Üzerine Bir Örneklem Çözümlemesi
}

\section{A Sample Analysis on Linguistic Items Revealing Writer's Gender at an Intuitive Level}

\author{
Turgay SEBZECİĞLU* ${ }^{*}$, Fince ÖZER ${ }^{* *}$ (®) Elif KARA** ${ }^{*}$, \\ Özlem ÖZDEMIR** ${ }^{* *}$, Senem KUZU**
}

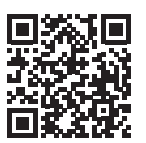

*Mersin Üniversitesi, Türk Dili ve Edebiyatı Bölümü, Mersin, Türkiye

**Mersin Üniversitesi, Sosyal Bilimler Enstitüsü, Mersin, Türkiye

ORCIDs: T.S. 0000-0002-9375-3217;

F.Ö. 0000-0001-5623-8489;

E.K. $0000-0001-6719-1161$

Ö.Ö. 0000-0002-9580-3492;

S.K. 0000-0002-1778-1689

Sorumlu yazar/Corresponding author: Turgay Sebzecioğlu (Doç. Dr.)

Mersin Üniversitesi, Türk Dili ve Edebiyatı Bölümü, Mersin, Türkiye

E-posta: sebzecioglu@yahoo.com

Başvuru/Submitted: 17.06 .2020

Kabul/Accepted: 30.06 .2020

Atıf/Citation: Sebzecioğlu, T. Özer, F. Kara, E. Özdemir, Ö. \& Kuzu, S. (2020). Yazar cinsiyetini sezgisel düzeyde ortaya çıkaran dilsel birimle üzerine bir örneklem çözümlemesi. Dilbilim Dergisi - Journal of Linguistics, 35, 35-62. https://doi.org/10.26650/jol.2020.009

\section{öz}

Bu çalışmanın amacı, yazılı bir metinde açık bir cinsiyet kodlayıcısının bulunmadığı durumlarda kadın ve erkek okuyucuların yazarın cinsiyetine ilişkin algılama stratejilerini belirlemek ve cinsiyet algılamasını ortaya çıkaran dilsel birimleri tespit etmektir. Türkçede erillik-dişillik bağlamında dil kullanıcısına özgü dilbilgisel cinsiyet kodlayıcısı bulunmadığından metinlere olan cinsiyet yansıması açık olarak sözlüksel, sezgisel olarak ise biçemsel (stylistic) düzlemde görülebilir. Dil kullanıcısı tarafından metin oluşturulurken bazı dilbilgisel yapıların cinsiyete özgü seçimlere duyarlı olduğu varsayılmıştır. Buna cinsiyet biçemi denebilir. Cinsiyete özgü seçimlerin Türkçe dil kullanıcıları açısından bilişsel bir ortaklık taşıdığı doğru bir varsayımsa, metin oluşturmada birçok dilbilgisel düzlemde gerçekleşen seçimlerin cinsiyet odaklı olduğu kabul edilebilir. Bunu anlamak üzere üç farklı yaş grubundan erkek ve kadın olarak eşit olarak bölümlenmiş katılımcılara bir erkek ve bir kadın olmak üzere gazete köşe yazarlarının sinema filmi üzerine yazdıkları iki farklı metin okutulmuş ve yazarların cinsiyetinin tahmin edilmesi istenmiş; ardından tahminlerine ait dayanakları metinden yola çıkarak göstermeleri beklenmiştir. Gözlemler, yazarın cinsiyetine ilişkin katılımcı çıkarımlarının dilbilgisel yapılardan çok sözlüksel birimlere dayandığını göstermiştir. Hızlı duygu değişimi, eleştirel dil kullanma gibi özellikler metnin cinsiyetine ilişkin çıkarımlarda katılımcıların belirlediği üst cinsiyet biçemleri olmuştur.

Anahtar kelimeler: Türkçe, Cinsiyet değişkeni, Yazılı söylem, Cinsiyet biçemi, Dilbilgisel birimler

\section{ABSTRACT}

This study aims to identify the strategies used by female and male readers to perceive the writer's gender when there is no explicit gender decoder in a written text. The study also seeks to determine the linguistic items that indicate gender perception. As the Turkish language has no grammatical gender decoders for its users in terms of masculinity and femininity, the reflection of gender in a text can be seen explicitly at a lexical level and intuitively at a stylistic level. When language users create a text, it is presumed that certain grammatical structures are sensitive to gender specific choices, which is called gender style. If it is a right presumption that gender specific choices are shared by speakers of Turkish on a cognitive basis, it can be accepted that, in creating a text, choices made on 
several grammatical levels are gender based. To investigate this, the study asked both female and male participants from three different age groups to read two different texts on cinema written by two columnists, one female and one male, and to guess the writers' gender. Later, the participants were expected to indicate the grounds for their guesses based on the text. This observation revealed that participants' inferences concerning the writer's gender were based on lexical units rather than grammatical structures. Characteristics such as rapid emotional changes and use of critical language were upper gender styles determined by the participants in their inferences concerning gender within the text.

Keywords: Turkish, Gender variable, Written discourse, Gender style, Grammatical items

\section{Giriş}

Bu çalışmanın amacı, yazılı bir metinde açık bir cinsiyet kodlayıcısının bulunmadığı durumlarda kadın ve erkek okuyucuların yazarın cinsiyetine ilişkin algılama düzeylerini belirlemek ve cinsiyet algılamasını ortaya çıkaran dilsel birimleri tespit etmektir. Dillerde cinsiyet değişkeni açısından hem sözlü hem de yazılı metinlerde kadın veya erkeğe özgü açık veya sezdirimsel birçok dilsel kodlayıcı bulunmaktadır. Cinsiyete özgü dil farklılıkları biyolojik, toplumsal ve hatta tarihsel nedenlere bağlı olarak açıklanabilir. Sözgelimi, Japoncada kadınlar tümcelerin sonuna ekledikleri \{ne\} ekiyle cinsiyetlerini belirtebilmektedir. Tai dilinde yinelenen bir olay kadınlar tarafindan eylemin yinelenmesiyle anlatılırken erkekler tarafindan eylemin sonuna \{mak\} eki getirilerek aktarılmaktadır (König 1992: 27-28).

Türkçede erillik-dişillik bağlamında dil kullanıcısına özgü dilbilgisel cinsiyet kodlayıcısı bulunmadığından metinlere olan cinsiyet yansıması açık olarak sözlüksel (lexical), sezgisel olarak ise biçemsel (stylistic) düzlemde görülebilir (Börekçi ve Tercanlıoğlu 1999: 46-47). Dil kullanıcısı tarafından metin oluşturulurken bazı dilbilgisel yapıların cinsiyete özgü seçimlere duyarlı olduğu varsayılabilir. Buna cinsiyet biçemi denebilir. Cinsiyete özgü seçimlerin Türkçe dil kullanıcıları açısından bilişsel bir ortaklık taşıdığı doğru bir varsayımsa, metin oluşturmada birçok dilbilgisel düzlemde gerçekleşen seçimlerin cinsiyet odaklı olduğu kabul edilebilir. Kısacası, dilbilgisel yapıların cinsiyete özgü bir sıklık içermesi, metin yazarının cinsiyetine 1şık tutacak bir gösterge olabilir. Bu doğrultuda, bu çalışma okuyucuların açık sözlüksel bir kodlayıcı olmadan metin yazarının cinsiyetini anlayacak dilbilgisel birimleri sezinleyip sezinleyemeyeceği sorusuyla ilgilenmektedir.

Türkçede kadın veya erkeğe özgü sözlüksel seçimlerin olabileceğini söylemiş̧tik. Sözlüksel düzlemde kadın ve erkeklere özgü birçok sözcük bulunabilmektedir. Öte yandan yazarın doğrudan cinsiyetini açığa vuran ifadeler kullanabilir. Sözgelimi, (1a)'da "kadınım”, "sahip olduğum kadınlık değerleri” (1b)'de ise "kendimden”, "Ayșe bana 'erkeklerin neden böyle olduklarını' sordu” ifadeleri metin yazarlarının cinsiyetini doğru tahmin etmemizi sağlayacak açık sözlüksel kullanımlardır. 


\begin{tabular}{|c|c|c|}
\hline$(1)$ & a. & Kadın yazara ait metin (açık sözlüksel kodlama düzlemi) \\
\hline & & $\begin{array}{l}\text { İ̧̧TE yine } 8 \text { Mart. Dünya Kadınlar Günü. Ben her } 8 \text { Mart'ta, iki duygu arasında kalıyorum. } \\
\text { Bir yanım acayip seviniyor. Çünkü kadınım ve kadın olmanın gücünü, yapıcılığını, } \\
\text { yaratıcılığını, şefkatini ve enerjisini tüm hücrelerimde hissediyorum. İçimden dans etmek, } \\
\text { kutlamak, coşkumu son damlasına kadar dışarı vurmak geliyor. Iyi ki kadınım! Sahip } \\
\text { olduğum kadınlık değerlerine şükrediyorum. (Arman, 2018, } 18 \text { Mart) }\end{array}$ \\
\hline \multirow[t]{2}{*}{$(2)$} & b. & Erkek yazara ait metin (açık sözlüksel kodlama düzlemi) \\
\hline & & $\begin{array}{l}\text { Bir erkek, türü ne olursa olsun, hayatta ne yapıyorsa hep bir kadın için yapar. Onu } \\
\text { tavlamak, kandırmak, kendine bağlamak, sevgisini kazanmak için... "Bunu da nereden } \\
\text { çıardın” diyorsanız yanıtım hazır: Kendimden! Ayşe Arman geçen gün erkeklerin, } \\
\text { bulabildikleri her firsatta 'şanslarını' denemek istediklerini yazdı. Tesadüf, Ayşe'nin } \\
\text { yazısının gazetede yayımlandığı gün bir başka gazeteci Ayşe ye (Özyılmazel) sabah } \\
\text { yürüyüşünde rastladım. Aynı konu açıldl, Ayşe bana 'erkeklerin neden böyle olduklarını' } \\
\text { sordu. (Yılmaz, 2018, 21 Ocak) }\end{array}$ \\
\hline
\end{tabular}

Buna karşın, dil kullanıcısı tarafından metin oluşturulurken bazı dilbilgisel yapıların erkek ve kadınlar tarafından seçimi veya yeğlenişi birbirinden farklılaşabilir. Dizgesel düzeyde olmasa da hemen hemen bütün dillerde böylesine bir seçimin olabileceği varsayılabilir. Türkçede de cinsiyete özgü dilbilgisel kodlama seçiminin betimlenmesi kadın ve erkek dilinin, dilin bütün düzlemlerindeki inceliklerinin anlaşılabilmesi açısından büyük önem arz etmektedir. Cinsiyete özgü seçimlerin Türkçe dil kullanıcıları açısından bilişsel bir ortaklık taşıdığı bir önvarsayım olarak kabul edilirse, metin oluşturmada birçok dilbilgisel düzlemde seçimin cinsiyet odaklı olduğu rahatlıkla düşünülebilir. Kısacası, dil kullanıcısının cinsiyetini kodlayan dilbilgisel bir belirtici olmamasına karşın belirli dilbilgisel yapıların cinsiyet biçemi açısından bir sıklık içermesi, metin yazarının cinsiyetine ışık tutacak bir gösterge olabilir.

Bu çalışma, okuyucuların açık sözlüksel bir kodlayıcı olmadan metin yazarının cinsiyetini ortaya çıkaracak dilbilgisel birimleri veya biçemleri sezinleyip sezinleyemeyeceği sorusuyla ilgilenmektedir. Bunu anlamak üzere üç farklı yaş grubundan her grupta eşit sayıda kadın ve erkeklerin katıldığg katılımcılara bir erkek ve bir kadının yazdığı iki farklı metin okutulmuş ve metin yazarlarının cinsiyetinin tahmin edilmesi istenmiş; ardından tahminlerine ait dayanakları metinden yola çıkarak açıklamaları beklenmiştir.

Bu çalışma ile ulaşılmak istenen hedefler maddeler halinde şöyle sıralanabilir: (i) Yazılı bir metinde açık bir cinsiyet kodlayıcı olmadığı durumlarda, kadın ve erkek okuyucuların yazarın cinsiyetine ilişkin algılama düzeylerini gözlemlemek; (ii) kadın ve erkeklerin bilişsel düzlemdeki cinsiyet algısını ortaya çıkaran dilsel birimleri tespit etmek ve son olarak (iii) katılımcılar tarafından cinsiyet değişkenine göre anlamlı bir düzenlilik içerdiği varsayılan dilsel birimlerin cinsiyetle olan ilintisini açıklamaktır.

Bu çalışma Giriş bölümü de dâhil olmak üzere toplam beş ana bölümden oluşmaktadır. İkinci bölüm olan Kavramsal Çerçeve bölümünde söylem, yazılı söylem, toplumsal değişke, cinsiyet değişkeni gibi temel kavramlar üzerinde durularak tanıtıcı açıklamalarda bulunulmuştur. Ardından gelen Araştırma Yöntemi başlığı altında çözümlemede kullanılan dil kullanıcılarına ait verilerin toplanma biçimine ve sınırlılıklarına değinilmiştir. Dördüncü bölüm olan Bulgular ve 
Değerlendirmede dil kullanıcılarından toplanan veriler çözümlenmiş, metin yazarının cinsiyetini algılama odağında ortaya çıkaran bulgular, çıkarımlar ve varsayımlar aktarılmıştır. Sonuç bölümünde ise, çalışmanın başında belirtilen amaçlar doğrultusunda biçimlenen araştırmanın bulguları üzerine genel bir değerlendirme yapılmıştır.

\section{Kavramsal Çerçeve}

Bu bölümde, çalışmanın çözümleme alanıyla ilgili sırasıyla söylem, yazılı söylem, toplumsal değişke, cinsiyet değişkeni kavramları üzerinde ana yönleriyle durulacaktır.

Çoğu zaman söz (statement), sözce/ifade (utterance) gibi kavramlarla yakın anlamlı olarak kullanılan söylem (discourse), gerçekte dilbilim ve göstergebilim kökenli olsa da ruhbilim, tarih, insanbilim ("antropoloji”), toplumdilbilim gibi sosyal bilimlerin birçok alanında geçerliliği olan bir terimdir (Howarth 2000; Mills 1997). Metinlere ait tür veya biçem anlamında kullanılabilen söylem, kimi zaman da metinlerin kullanımına veya konusuna gönderimde bulunan bir kavram olarak karşımıza çıkmaktadır: politik söylem, medya söylemi, emperyalist söylem, nefret söylemi, ırkçı söylem vb. (Baker 2006: 3). Farklı farklı tanımlarına rağmen en genel anlamıyla söylem "konuşma ve yazmadaki iletişim” veya “dilin sözlü ya da yazılı gerçekleşimi” biçiminde tanımlanmıştır (Cambridge Dictionary 2018; Vardar ve diğ. 1998). Bütün bu tanımlarda altı çizilmesi gerekilen nokta söylem kavramının yalnızca konuşma dilini değil yazı dilini de kapsamasıdır. Bundan dolayı, bu çalışmada kullanılan yazılı söylem terimi, söylemin genellikle "konuşma diliyle ilgili olduğu" (bk. Crystal 2003) biçimindeki yanlış algıya rağmen, yadırganmamalıdır. İşin tuhafı metin (text) kavramı söylemin aksine daha çok yazılı dil için kullanılsa da konuşma diline ait dil örüntüleri için de metin kavramı kullanılabilmektedir (bk. Finch 2000). Dolayısıyla, bu çalışmanın kapsamı açısından ister yazılı söylem diyelim isterse de yazılı metin terimini kullanalım hemen hemen aynı kavrama gönderimde bulunmuş olacağız. Öte yandan, her ne kadar söylem, "bir ya da birden fazla tümceden oluşan ve başı ve sonu olan bildiri” (bk. Vardar ve diğ. 1998) biçiminde tanımlansa da bu çalışmada birden fazla tümceden oluşan söylem parçaları üzerinden dil kullanıcılarının cinsiyet algısı gözlemlenecektir. Gerçekte de alanyazında çözümlenen dil parçalarına ve yapılan tanımlara bakıldığında söylem algısı birden fazla tümce üzerine odaklanmaktadır (bk. Crystal 2003; Finch 2000). Bunun nedeni, belli bir bağlamda iletişim (communication) amaçlı dil kullanımının söylem çözümlemesi açısından daha anlamlı olmasıdır. Söylem çözümleyicileri için dil daima iletişimseldir ve iletişim amaçlı olarak kurgulanır (Schiffrin 1996: 3). Alanyazında iletişim ile söylem kavramlarının yüksek bir eşdizimliliğe sahip olduğu rahatlıkla söylenebilir.

Söylem kavramının ardından yazılı söylem (written discourse), kavramı üzerine biraz daha odaklanabiliriz. Yazılı söylem, sözlü söylemden farklı olarak işitsel değil görsel bir niteliğe sahiptir. Sözlü dilde olduğu gibi geçici üretimler çok az görülürken kalıcı üretimler daha fazladır. Geçmişe kıyasla yazılı söylemdeki geçici ve anlık üretimlerin Genel Ağ üzerindeki sosyal medya paylaşımlarıyla arttığı söylenebilir. Sözlü söylem oluşturulurken çok fazla plan 
ve değişiklik yapma şansı bulunmazken yazılı söylemde uzun süreli plan yapma ve ortaya çıkan metni yeniden düzenleme olanağı bulunmaktadır. Sözlü söylemde etkileşim kurma, geri bildirim alma gibi olanaklar bulunurken yazılı söylemde bu tür olanaklar çoğunlukla bulunmaz. Sözlü söylemde konuşucu ve dinleyici aynı zaman ve konumda bulunmanın getirdiği şeyleri iletişim örüntüsünde paylaşırlarken yazılı söylemde ortaya çıkan yazar-okuyucu etkileşıminde zaman ve konum konusunda bir ortaklık bulunmak zorunda değildir. Yazılı söylem ve sözlü söylemde bağlaşıklık, bağdaşıklık, işbirliği ilkesi, kibarlık stratejisi gibi ortak söylem olguları bulunabilir; ancak, yazılı dil yazarın jestlerini, mimiklerini, konuşma ezgilerini aktarmak noktasında daha güçsüzdür (Renkema 2004; Deborah ve Panović 2014).

Bu çalışma, cinsiyete özgü dil kullanımı ve dil algısı üzerinden dilin cinsiyete özgü yönüyle ilgilenmektedir. Toplumdilbilimde $a \breve{g} l z$ (dialect), bireydil (idiolect) gibi bir dil türü olan toplumsal değişke (sociolect), cinsiyet kullanımlarını da içine almaktadır. Toplumsal değişke (sociolect), kavramı topluluk dili ya da grup dili olarak da adlandırılabilmektedir. Her toplum, kültür ve bu kültürleri içine alan yaşam koşulları değişkenlik gösterir. Aynı topluluk ve kültür içinde değişkenlik gösteren yaş, sosyoekonomik durum, cins, arkadaş, aile, meslek kendi içinde toplumsal değişkeyi (sociolect) oluşturur. Din ve coğrafya toplumsal değişkenin temellerini oluşturan en önemli unsurdur. Meslek dillerinin kullanım biçimi olan topluluk dilleri çeşitlilik gösterir: meslek dili (vocational language), çocuk dili (language enfantin), yetişkin dili (adult langauge), yargl dili (legalese), bilim dili (scientific language), din dili (religious language), cins dili (gender language) vb. (Karaağaç 2011). Toplumdilbilimi, farklı yöntemle ve kuramlarla insan dilinin toplumsal yönünü ele alır (Sebzecioğlu ve Coşgun Özgür 2015). Bireysel dil ile mensup olunan toplumun dili ve sözgelimi cins dilini de (genderlect) kapsayan toplumsal değişke arasında toplumsal değişkenler etrafında değerlendirmelerde bulunmaktadır (Önem 2011; Toklu 2003). Toplumsal değişke (sociolect) bağlamında cins dili olan kadın ve erkeğin dili aynı dili konuşan toplumlarda her zaman farklılık göstermektedir. Daha çok konuşma diline yansıyan bu cins dili, sözgelimi erkeği ölçüt alan ve kadına karşı tutum sergileyen deyimlerde de görülür (Aliefendioğlu 1997). Sonuç olarak toplumsal değişke, yaşanan kültürün özelliklerini yansıtan, yaşama biçimlerinden etkilendiği gibi onları da etkilemeye devam eden bir kavramdır.

Cinsiyet değişkeni (gender variable), özellikle toplumdilbilim çerçevesinde biyolojik cinsler arasında görülen dilsel farklılıklar olarak tanımlanabilir. Bu çalışmada cinsiyet değişkeni erkek ve kadın olmak üzere ikil olarak ele alınmıştır. Türkçede cinsiyet değişkeni açık olarak sözlüksel düzlemde incelenebilir. Türkçe ve diğer Altay dillerinde dilbilgisel cinsiyetin bulunmadığ yaygın bir kanıdır (dilbilgisel cinsiyet için bk. Aksan 1997; Börekçi ve Tercanoğlu 1999; Doğan 2011; Korkmaz 1992; Sebzecioğlu 2016). Buna karşın, Türkçede diğer dillerde olduğu gibi yazılı metinlerde kadın ve erkeğe özgü sezgisel kodlayıcıların biçemsel düzlemde var olduğu kimi bulgular üzerinden gösterilmiştir. 


\section{Araştırma Ve Çözümleme Yöntemi}

Araştırmaya gönüllülük esasına göre katılan katılımcılar üç farklı yaş grubundan seçilmiştir. 15 ile 18 yaş aralığında bulunan 30 lise öğrencisi, 19 ile 25 yaş aralığında bulunan 30 üniversite öğrencisi ve farklı mesleklerden 35 yaş üzeri 30 tane yetişkin. Son katılımcı grupta yetişkin bireyler düşünüldüğünden 35 ve üzeri yaşta olanların “yetişkin olmak” bağlamında daha kabul edilebilir olacağı varsayılmış 25-35 yaş arası bireyler bu bağlamda çalışmaya dahil edilmemiştir. Toplam 30 bireyden oluşan her yaş grubu, cinsiyet değişkenine göre 15 kız 15 erkek olmak üzere eşit olarak bölümlenmiştir. Araştırma sürecinde yer alan toplam katılımcı sayısı 90’dır.

Tablo 1: Katılımc1ların grup ve cinsiyet grubuna göre sayısal dağılımları

\begin{tabular}{|c|c|c|c|c|c|}
\hline \multicolumn{2}{|c|}{ Lise Öğrencileri } & \multicolumn{2}{c|}{ Üniversite Öğrencileri } & \multicolumn{2}{c|}{30 Yaş Üstü Yetişkinler } \\
\hline $15 \mathrm{k1z}$ & 15 erkek & $15 \mathrm{k1z}$ & 15 erkek & $15 \mathrm{k1z}$ & 15 erkek \\
\hline \multicolumn{2}{|c|}{30 lise öğrencisi } & \multicolumn{2}{|c|}{30 üniversite öğrencisi } & \multicolumn{2}{|c}{} \\
\hline Toplam: 90 katılıkin birey
\end{tabular}

Katılımcılara uygulama öncesinde çalışmanın konusu ile ilgili herhangi bir bilgi verilmemiştir. Uygulama sırasında katılımcıların birbirleriyle olan etkileşimini önlemek adına ayrı ayrı sıralara oturmaları sağlanmıştır. Ardından Ek 1 ve Ek 2'de gösterilen veri toplama formları dağıtılmış ve form hakkında kısa ama açıklayıcı bir bilgi sunumu yapılmıştır.

Veri toplama formunda kurgusal olmayan (nonfiction) iki düz yazı metin parçası bulunmaktadır. Metinlerden biri kadın, diğeri ise erkek bir yazara aittir. Metinler, sinema filmleri hakkında yazılan iki köşe yazısından oluşmaktadır. Bu metinler çözümlemede 1. Metin ve 2. Metin olarak kodlanmıştır. 1. Metin kadın bir yazar olan Ayşe Arman'a ait "Çok da Şey etmemek Lazım!” adlı yazıdır (bk. Ek 1). 2. Metin ise erkek bir yazar olan Cengiz Semercioğlu'na ait “Oscar'a Bu Kadar Yakınken Ayla’ya Yapılanlara Bakın” adlı yazıdır (bk. Ek 2).

Araştırmada yer alan katılımcılara seçilen metinleri sırayla okumaları ve yazarının kadın veya erkek olup olmadığı noktasında bir tahminde bulunmaları istenmiştir. Yazar cinsiyetine ilişkin tahminlerin sezgisel düzeyde kalması için metinlerde cinsiyet göstergesi olacak açık sözlüksel birimlerin yer almamasına özen gösterilmiştir. Sözgelimi, metinlerde yazarın kadın olduğunu ortaya çıkaracak "cicim”, “anayım ben” gibi; erkek olduğunu ortaya çıkaracak "ulan", "bizim hatuna bir sorayım” gibi sözcük ve ifadelere yer verilmemiştir.

Katılımcıların sezgisel düzeyde yaptıkları tahminlerini algısal düzleme çekmek için her metin için ikinci bir soru sorulmuştur: Neden yukarıdaki metnin bir kadına/erkeğe ait olduğunu düşündünüz? Bunu size hangi ek, hangi sözcük ya da hangi dilsel yapı düşündürttü? Nedenlerinizi metinden yola çıkarak aşağıdaki kutucuğa yazınız. Katılımcıların verdikleri yanıtlardan yola çıkarak verilen metinlerin özellikle dilbilgisi yapılarında cinsiyete özgü bir seçimler zinciri taşıyıp taşımadığına bakılmıştır.

Farklı yaş gruplarından erkek ve kadınların kendilerine verilen 1. Metin (kadın yazar) ve 2. Metin'e (erkek yazar) ilişkin yazar cinsiyetine ilişkin tahminlerini biçimlendiren temel kavram ve işlevler Tablo (2)'de karşıtlık üzerine kurulu olarak verilmiştir. Duygusal anlatım- 
duygusal olmayan anlatım, kadınsı söylem-erkeksi söylem gibi karşıtlıklar katılımcıların yanıtlarından ortaya çıkan doğal bir görünüm olduğu gibi cinsiyet değişkenini benzemezlikler ("karşıtllklar”) üzerinden ortaya koymak adına yararlı da olmuştur. İşlevler karşıtllık temelinde oluşturulduğundan kimi işlevlerin karşıtları bu makalenin yazarları tarafından eklenmiştir. Bundan dolayı, bu tablodaki soyut anlatım, edebî olmayan dil, ölçünlü (standart) dil, eleştirel olmayan dil, argo içermeyen dil kullanımı, empati kuramama, olasılıklara dayalı anlatım gibi kimi işlevler karşıtları yer alsa da kendileri katılımcıların yanıtları içerisinde yer almamıştır.

Tablo 2: Metinlerdeki yazar cinsiyetine ilişkin tahminleri biçimlendiren temel kavram ve işlevler

\begin{tabular}{|c|c|c|c|}
\hline 1 & duygusal anlatım & 2 & duygusal olmayan anlatım \\
\hline 3 & kadınsı söylem & 4 & erkeksi söylem \\
\hline 5 & resmi bir dil kullanımı & 6 & resmi olmayan (laubali) bir dil kullanımı \\
\hline 7 & sert anlatım & 8 & yumuşak anlatım \\
\hline 9 & somut anlatım & 10 & soyut anlatim \\
\hline 11 & kibar dil kullanımı & 12 & kaba dil kullanımı \\
\hline 13 & edebî dil & 14 & edebî olmayan dil \\
\hline 15 & konuşma dili & 16 & ölçünlü (standart) dil \\
\hline 17 & eleştirel dil & 18 & eleştirel olmayan dil \\
\hline 19 & argo kullanımı & 20 & argo içermeyen dil kullanımı \\
\hline 21 & $\begin{array}{l}\text { söylediklerini yumuşatma gereği } \\
\text { duyma }\end{array}$ & 22 & söylediklerini yumuşatma gereği duymama \\
\hline 23 & öznel anlatım & 24 & duyguları belli etmeyen nesnel anlatım \\
\hline 25 & samimi ve sıcak anlatım & 26 & samimi ve sıcak olmayan anlatım \\
\hline 27 & abartılı duygu aktarımı & 28 & abartılı olmayan duygu aktarımı \\
\hline 29 & ayrintılı anlatım & 30 & ayrıntılara yer vermeyen anlatım \\
\hline 31 & yalın, sade ve düz anlatım & 32 & süslü, ağdalı ve bulanık anlatım \\
\hline 33 & sorgulayıcı bir dil kullanımı & 34 & sorgulamayan bir dil kullanımı \\
\hline 35 & kesin ifadelerle anlatım & 36 & olasılıklara dayalı anlatım \\
\hline 37 & empati kurabilme & 38 & empati kuramama \\
\hline 39 & betimleyici bir dil kullanımı & 40 & betimleyici olmayan bir dil kullanımı \\
\hline 41 & heyecanlı ve coşkulu anlatım & 42 & heyecan ve coşku içermeyen anlatım \\
\hline 43 & anlatımda duygusal çeşitlilik & 44 & anlatımda duygusal çeşitlilik içermeme \\
\hline 45 & iknaya ve ispata yönelik anlatım & 46 & onaylanma gereksinimi duymayan anlatım \\
\hline 47 & hızlı duygu değişimi & 48 & hızlı olmayan duygu değişimi \\
\hline 49 & içeriğin kadın beğenisini yansıtması & 50 & içeriğin erkek beğenisini yansıtması \\
\hline 51 & ayrıntıya dikkat çekme & 52 & ayrıntıya dikkat çekmeme \\
\hline 53 & açıklayıcı anlatım & 54 & açıklayıcı olmayan anlatım \\
\hline
\end{tabular}


Tablo (2)'de bulunan işlevler görünürde birkaç “tuhaflık” içermektedir. İlki, kimi işlevlerin birbirinden ayrılamayacak kadar benzer olmasıdır. İkincisi ise duygusal anlatım gibi erkek ve kadın değişkenini ortaya koyacak açık bir işleve karşın kadınsı söylem gibi diğer işlevleri de içine alacak kadar genel işlevlerin yer almasıdır. İşlevler açısından son tuhaflık veya bakışımsızlık olarak yalın, sade ve düz anlatım gibi biçeme ve hatta biçime yönelik işlevlerin yanında hızlı duygu değişimi gibi yalnızca metnin içeriğine yönelik işlevlerin bulunması gösterilebilir. Şimdi sırasıyla söz konusu "tuhaflıklar”' açıklamaya çalışalım. Öncelikle işlevlerin birbirine benzer olması aynı olduklarını göstermez. Sözgelimi, duygusal anlatım ile samimi ve sıcak anlatım birbirine çok yakın işlevler gibi dursa da tam olarak aynı işleve gönderimde bulunmamaktadır. Duygusal bir anlatım samimiyet veya dostane bir niteliğe sahip olmayabilir. Her duygusal anlatım abartılı olmak zorunda değildir. Abartılı anlatımın da mutlaka duygusal olmasına gerek yoktur. Bütün bu farklara rağmen benzer işlevleri ortak bir küme içerisinde değerlendirmek mümkündür. Sözgelimi, katılımcıların açıklama ve belirlemelerinden yola çıkılarak duygusal anlatım, heyecanlı ve coşkulu anlatım, abartıl duygu aktarımı, samimi ve sıcak anlatım, öznel anlatım, anlatımda duygusal çeşitlilik, içeriğin kadın beğenisini yansıtması, hızlı duygu değişimi, ayrıntılı anlatım gibi işlevler kadınsı söylem kümesi; duygusal olmayan anlatım, sert anlatım, duyguları belli etmeyen nesnel anlatım, yalın, sade ve düz anlatım, iknaya ve ispata yönelik anlatım, abartılı olmayan duygu aktarımı, resmi bir dil kullanımı, eleştirel dil, argo kullanımı, kesin ifadelerle anlatım, içeriğin erkek beğenisini yansıtması, kaba dil kullanımı, heyecan ve coşku içermeyen anlatım, sert anlatım, somut anlatım gibi işlevler erkeksi söylem kümesi olarak etiketlenebilir.

\section{Bulgular ve Değerlendirme}

Bu bölümde bir önceki bölümde temelini katılımcıların belirlediği işlevler (bk. Tablo (2)) ve bu işlevlere getirdikleri dilsel kanıtlar etrafında kadın ve erkek yazara ilişkin tahminlerin ortaya çıkardığ 1 görünüme bakılacaktır. Çözümleme ve değerlendirme sırasıyla kadın yazara ait olan 1. Metin ve erkek yazara ait olan 2. Metin üzerinden yapılacaktır.

\subsection{Kadın Yazara (1. Metin'e) Yönelik Bulgular ve Dĕgerlendirmeler}

Kadın yazara ilişkin tespitlerdeki işlevler Tablo (3)'te dilbilgisel görünümleriyle birlikte verilmiştir. Tabloda bulunan Katılımcıların ortaya koyduğu dilsel kanıtlar kutucuğunda katılımcıların metinden yaptığı kanıt niteliğindeki alıntılar tırnak içinde, metin hakkındaki yorumları ise tırnaksız verilmiştir. 
Tablo 3: Kadın katılımcılar açısından 1. Metin'deki kadın yazarın cinsiyetine ilişkin tahminleri biçimlendiren kavramlar

\begin{tabular}{|c|c|c|}
\hline Kavram ve işlevler & Katılımcıların ortaya koyduğu dilsel kanıtlar & Sıklık \\
\hline kadınsı söylem & 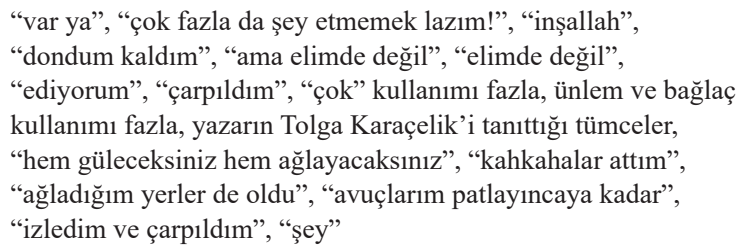 & 19 \\
\hline duygusal anlatım & $\begin{array}{l}\text { "hem güleceksiniz hem ağlayacaksınız", "çarpıldım", "ağladığım } \\
\text { yerler de oldu" }\end{array}$ & 15 \\
\hline heyecanlı ve coşkulu anlatım & $\begin{array}{l}\text { "belli yerlerinde kahkahalar attım ama ağladığım yerler de oldu. } \\
\text { Finalde de dondum kaldım!", ünlem işaretinin çokça kullanımı }\end{array}$ & 9 \\
\hline abartılı duygu aktarımı & "kahkahalar attım ama ağladığım yerler de oldu" & 6 \\
\hline erkeksi söylem & $\begin{array}{l}\text { “var ya”, "Mutlaka bu filmi izleyin!”, "şey” sözcüğü fazla } \\
\text { kullanılmış, "avuçlarım patlayıncaya kadar", "adam” }\end{array}$ & 4 \\
\hline samimi ve sicak anlatım & "şey" & 4 \\
\hline öznel anlatım & "hem güleceksiniz hem ağlayacaksınız”, "çarpıldım” & 3 \\
\hline argo kullanımı & “var ya”, “avuçlarım patlayıncaya kadar”, "adam”, “çarpıldım” & 2 \\
\hline kaba dil kullanımı & avuçlarım acıyıncaya kadar dememiş "patlayıncaya kadar” demiş & 3 \\
\hline $\begin{array}{l}\text { iknaya ve ispata yönelik } \\
\text { anlatım }\end{array}$ & & 3 \\
\hline anlatımda duygusal çeşitlilik & "kahkahalar attım ama ağladığım yerler de oldu" & 2 \\
\hline yalın, sade ve düz anlatım & & 2 \\
\hline $\begin{array}{l}\text { içeriğin kadın beğenisini } \\
\text { yansıtması }\end{array}$ & & 1 \\
\hline hızlı duygu değişimi & & 1 \\
\hline konuşma dili & & 1 \\
\hline $\begin{array}{l}\text { samimi ve sicak olmayan } \\
\text { anlatım }\end{array}$ & & 1 \\
\hline ayrıntılı anlatım & & 1 \\
\hline $\begin{array}{l}\text { ayrıntılara yer vermeyen } \\
\text { anlatım }\end{array}$ & & 1 \\
\hline ayrıntıya dikkat çekmeme & & 1 \\
\hline
\end{tabular}

Tablo (3)'te kadın katılımcıların ortaya koyduğu kavram ve işlevler ile dilsel kanıtlar 1. Metin'in yazarının yüksek oranda doğru tahmin edildiğini göstermektedir. En fazla sıklığa sahip işlev kadınsı söylem (19 kez dile getirilmiş) olduğu gibi en fazla kanıt da yine bu işlev için ortaya konmuştur. Onu takip eden duygusal anlatım, heyecanlı ve coşkulu anlatım, abartılı duygu aktarımı işlevleri de yine kadın katılımcıların metnin yazarının kadın olduğunu gösteren işlevler olarak belirtilmiştir. Tablo (4), Tablo (3)'te ortaya çıkan işlev dağılımlarının sıklığını 
kadın-erkek yazar değiştirgeni bağlamında görmek açısından daha net bir resim sunmaktadır. Tablo (4)'te yer alan kadınsı söylem, duygusal anlatım, heyecanlı ve coşkulu anlatım, abartılı duygu aktarımı, samimi ve sıcak anlatım, öznel anlatım, anlatımda duygusal çeşitlilik, içeriğin kadın beğenisini yansıtması, hızlı duygu değişimi, ayrıntılı anlatım biçiminde sıralanan işlevler, katılımcılara göre metnin kadın bir yazara ait olduğunu kanıtlamaktadır. Kadın yanıtı için öne sürülen işlevlerin sıklık sayısı 61 iken erkek yanıtı için öne sürülen işlevlerin sıklık sayısı 17'dir.

Tablo 4: Kadın katılımcılar açısından 1. Metin (kadın yazar) için erkek ve kadın yanıtını destekleyen işlevleri kümelendirerek yazar cinsiyeti açısından sıklık sayılarını değerlendirme

\begin{tabular}{|c|c|c|c|}
\hline & & İşlevler ve sıklık sayıları & Toplam \\
\hline \multirow{10}{*}{$\begin{array}{l}\text { kadın yanıtı için öne sürülen } \\
\text { işlevler }\end{array}$} & 1 & kadınsı söylem: 19 & \multirow[t]{10}{*}{61} \\
\hline & 2 & duygusal anlatım: 15 & \\
\hline & 3 & heyecanlı ve coşkulu anlatım: 9 & \\
\hline & 4 & abartılı duygu aktarımı: 6 & \\
\hline & 5 & samimi ve sıcak anlatım: 4 & \\
\hline & 6 & öznel anlatım: 3 & \\
\hline & 7 & anlatımda duygusal çeşitlilik: 2 & \\
\hline & 8 & içeriğin kadın beğenisini yansıtması: 1 & \\
\hline & 9 & hızlı duygu değişimi: 1 & \\
\hline & 10 & ayrıntılı anlatım: 1 & \\
\hline \multirow{8}{*}{$\begin{array}{l}\text { erkek yanıtı için öne sürülen } \\
\text { işlevler }\end{array}$} & 1 & erkeksi söylem: 4 & \multirow[t]{9}{*}{17} \\
\hline & 2 & kaba dil kullanımı: 3 & \\
\hline & 3 & iknaya ve ispata yönelik anlatım: 3 & \\
\hline & 4 & argo kullanımı: 2 & \\
\hline & 5 & yalın, sade ve düz anlatım: 2 & \\
\hline & 6 & samimi ve sicak olmayan anlatım: 1 & \\
\hline & 7 & ayrıntılara yer vermeyen anlatım: 1 & \\
\hline & 8 & ayrıntıya dikkat çekmeme: 1 & \\
\hline öne sürülen toplam işlev sayısı & 18 & & \\
\hline
\end{tabular}

Erkek katılımcıların kadın yazara ilişkin ortaya koyduğu işlevler Tablo (5)'te gösterilmiştir. Tabloda bulunan Katılımcıların ortaya koyduğu dilsel kanıtlar kutucuğunda katılımcıların metinden yaptığı alıntılar tırnak içinde, metin hakkındaki yorumları ise tırnaksız verilmiştir. 
Tablo 5: Erkek katılımcılar açısından 1. Metin'deki kadın yazarın cinsiyetine ilişkin tahminleri biçimlendiren kavramlar

\begin{tabular}{|c|c|c|}
\hline Kavram ve işlevler & Katılımcıların ortaya koyduğu dilsel kanıtlar & Sıklık \\
\hline duygusal anlatım & $\begin{array}{l}\text { "var ya", “şey”, ağladığım yerler de oldu”, "çarpıldım”, } \\
\text { "kahkahalar attım”, "dondum kaldım”, "bana çok iyi geldi”, } \\
\text { "inşallah size de iyi gelir” biçiminde temennide bulunması, } \\
\text { sözcük seçimi }\end{array}$ & 17 \\
\hline kadınsı söylem & $\begin{array}{l}\text { "şey etmemek", "ya", yazarın geveze olması, "kahkahalar } \\
\text { attım", "dondum kaldım", "çarpıldım”, "ağladığım yerler } \\
\text { de oldu", "var ya", "çok fazla da şey etmemek lazım", } \\
\text { "avuçlarım patlayıncaya kadar", "bana çok iyi geldi”, uzun } \\
\text { tümceler kullanılmış, "ama ağladığım yerler de oldu", "adam”, } \\
\text { eksiltili tümce kullanımı, 3. çoğul kullanımı, seslenme biçimi, } \\
\text { sözdizimsel yapı }\end{array}$ & 16 \\
\hline heyecanlı ve coşkulu anlatım & "şey", "mutlaka bu filmi izleyin" & 6 \\
\hline abartılı duygu anlatımı & $\begin{array}{l}\text { "çarpıldım”, "dondum kaldım”, "avuçlarım patlayıncaya } \\
\text { kadar", "var ya", "Tolga Karaçelik'i tebrik ediyorum”, "bana } \\
\text { çok iyi geldi, inşallah size de öyle gelir" }\end{array}$ & 5 \\
\hline erkeksi söylem & $\begin{array}{l}\text { "var ya", "çok fazla da şey etmemek”, "size de öyle gelir", } \\
\text { "çarpıldım”, "adam hayatında üç film yapmış", bağıntısız ve } \\
\text { kopuk ("eksiltili”") tümceler }\end{array}$ & 5 \\
\hline kaba dil kullanımı & "var ya" & 3 \\
\hline ayrıntılı anlatım & & 3 \\
\hline samimi ve sıcak anlatım & "var ya" & 2 \\
\hline hızlı duygu değişimi & & 2 \\
\hline $\begin{array}{l}\text { süslü, ağdalı ve bulanık } \\
\text { anlatım }\end{array}$ & & 2 \\
\hline duygusal olmayan anlatım & & 2 \\
\hline $\begin{array}{l}\text { onaylanma gereksinimi } \\
\text { duymayan anlatım }\end{array}$ & & 2 \\
\hline konuşma dili & & 2 \\
\hline argo kullanımı & & 1 \\
\hline kibar dil kullanımı & & 1 \\
\hline ayrıntılara dikkat çekmeme & & 1 \\
\hline $\begin{array}{l}\text { ayrıntılara yer vermeyen } \\
\text { anlatım }\end{array}$ & & 1 \\
\hline öznel anlatım & & 1 \\
\hline
\end{tabular}

Tablo (5)'te kadın katılımcıların ortaya koyduğu kavram ve işlevler ile dilsel kanıtlar 1. Metin'in yazarının yüksek oranda doğru tahmin edildiğini göstermektedir. En fazla sıklığa sahip işlev duygusal anlatım (17 kez dile getirilmiş) olmuştur. Onu takip eden kadınsı söylem, heyecanlı ve coşkulu anlatım, abartılı duygu aktarımı işlevleri de yine erkek katılımcılar tarafından metnin yazarının kadın olduğunu gösteren işlevler olarak belirtilmiştir. En fazla 
kanıt kadınsı söylem işlevi üzerine sunulmuştur. Tablo (6), Tablo (5)'te ortaya çıkan işlev dağılımlarının sıklığını kadın-erkek yazar değiştirgeni bağlamında görmek açısından daha net bir resim sunmaktadır. Tablo (6)'da yer alan duygusal anlatım, kadınsı söylem, heyecanlı ve coşkulu anlatım, abartılı duygu aktarımı, ayrıntılı anlatım, samimi ve sıcak anlatım, hızlı duygu değişimi, süslü, ăgdalı ve bulanık anlatım, kibar dil kullanımı, öznel anlatım biçiminde sıralanan işlevler, katılımcılara göre metnin kadın bir yazara ait olduğunu kanıtlamaktadır. Kadın yanıtı için erkek katılımcılar tarafından öne sürülen işlevlerin sıklık sayısı 55 iken erkek yanıtı için öne sürülen işlevlerin sıklık sayısı 13’tür.

Tablo 6: Erkek katılımcılar açısından 1. Metin (kadın yazar) için erkek ve kadın yanıtını destekleyen işlevleri kümelendirerek yazar cinsiyeti açısından sıklık sayılarını değerlendirme

\begin{tabular}{|c|c|c|c|}
\hline & & İșlevler ve sıklık sayıları & Toplam \\
\hline \multirow{10}{*}{$\begin{array}{l}\text { kadın yanıtı için öne sürülen } \\
\text { işlevler }\end{array}$} & 1 & duygusal anlatım: 17 & \multirow[t]{10}{*}{55} \\
\hline & 2 & kadınsı söylem: 16 & \\
\hline & 3 & heyecanlı ve coşkulu anlatım: 6 & \\
\hline & 4 & abartılı duygu anlatımı: 5 & \\
\hline & 5 & ayrıntılı anlatım: 3 & \\
\hline & 6 & samimi ve sicak anlatım: 2 & \\
\hline & 7 & hızlı duygu değişimi: 2 & \\
\hline & 8 & süslü, ağdalı ve bulanık anlatım: 2 & \\
\hline & 9 & kibar dil kullanımı: 1 & \\
\hline & 10 & öznel anlatım: 1 & \\
\hline \multirow{5}{*}{$\begin{array}{l}\text { erkek yanıtı için öne sürülen } \\
\text { işlevler }\end{array}$} & 1 & erkeksi söylem: 5 & \multirow[t]{6}{*}{13} \\
\hline & 2 & kaba dil kullanımı: 3 & \\
\hline & 3 & duygusal olmayan anlatım: 2 & \\
\hline & 4 & onaylanma gereksinimi duymayan anlatım: 2 & \\
\hline & 5 & argo kullanımı: 1 & \\
\hline öne sürülen toplam işlev sayısı & 15 & & \\
\hline
\end{tabular}

1. Metin üzerine kadın ve erkek katılımcıların tahminleri, ortaya koydukları sıklık değerleri açısından değerlendirildiğinde kadınların erkeklere göre metin yazarının cinsiyetini küçük bir oranla daha doğru tahmin ettikleri anlaşılmaktadır. Tablo (4) ile Tablo (6)'da yer alan değerler yeniden karşılaştırıldığında bu daha iyi anlaşılacaktır. Tablo (4)'te görüldüğü gibi kadın katılımcılar 1. Metnin yazarını işlevlere yaptıkları 61 gönderimle, erkek katılımcılar ise (bk. Tablo (6)) işlevlere yaptıkları 55 gönderimle metnin yazarını doğru tahmin etmişlerdir. Kadın katılımcıların bir diğer farkı ise tahminlerini daha çok gönderimde bulunarak belirtmiş olmalarıdır. $61+17=78$ (bk. Tablo (4)). Erkek katılımcılar ise işlevlere toplamda $68(55+13)$ gönderimde bulunmuşlardır. Buradan yola çıkarak kadınların metnin yazarına ilişkin tahminde bulunurken daha ayrıntılı düşündüklerini söylemek mümkündür. Kadınlar 1. Metnin doğrudan 
yazarın cinsiyetine yönelik tahminlerinde toplam 18 tür işlev ortaya koymuşken erkekler 15 işlev ortaya koymuşlardır (krş. Tablo (4) ile Tablo (6)).

1. Metin'deki yazar cinsiyetine ilişkin tahminleri biçimlendiren kavramların cinsiyete göre dağılımı aşağıdaki tabloda verilmiştir. Tablodaki kadınların sıklık yüzdesi toplam kadın katılımcı sayısı olan 45, erkeklerin yüzdesi ise toplam erkek sayısı olan 45 üzerinden hesaplanmıştır.

Tablo 7: Kadın yazarın cinsiyetine ilişkin tahminleri biçimlendiren kavramların katılımcıların cinsiyetine göre sıklık dağılımı

\begin{tabular}{|c|c|c|c|c|}
\hline \multirow[b]{2}{*}{ Kavram ve işlevler } & \multicolumn{2}{|c|}{ Kadınlar } & \multicolumn{2}{|c|}{ Erkekler } \\
\hline & Sıklık & Sıklık Yüzdesi & Sıklık & Sıklık Yüzdesi \\
\hline kadınsı söylem & 19 & $\% 42,22$ & 16 & $\% 35,55$ \\
\hline duygusal anlatım & 15 & $\% 33,33$ & 17 & $\% 37,77$ \\
\hline heyecanlı ve coşkulu anlatım & 9 & $\% 20$ & 6 & $\% 13,3$ \\
\hline abartılı duygu anlatımı & 6 & $\% 13,3$ & 5 & $\% 11,11$ \\
\hline erkeksi söylem & 4 & $\% 8,8$ & 5 & $\% 11,11$ \\
\hline samimi ve sıcak anlatım & 4 & $\% 8,8$ & 2 & $\% 4,4$ \\
\hline kaba dil kullanımı & 3 & $\% 6,6$ & 3 & $\% 6,6$ \\
\hline öznel anlatım & 3 & $\% 6,6$ & 1 & $\% 2,2$ \\
\hline ayrıntılı anlatım & 1 & $\% 2,2$ & 3 & $\% 6,6$ \\
\hline hızlı duygu değişimi & 1 & $\% 2,2$ & 2 & $\% 4,4$ \\
\hline argo kullanımı & 2 & $\% 4,4$ & 1 & $\% 2,2$ \\
\hline konuşma dili & 1 & $\% 2,2$ & 2 & $\% 4,4$ \\
\hline $\begin{array}{l}\text { iknaya ve ispata yönelik } \\
\text { anlatım }\end{array}$ & 3 & $\% 6,6$ & - & $\% 0$ \\
\hline anlatımda duygusal çeşitlilik & 2 & $\% 4,4$ & - & $\% 0$ \\
\hline $\begin{array}{l}\text { süslü, ağdalı ve bulanık } \\
\text { anlatım }\end{array}$ & - & $\% 0$ & 2 & $\% 4,4$ \\
\hline yalın, sade ve düz anlatım & 2 & $\% 4,4$ & - & $\% 0$ \\
\hline $\begin{array}{l}\text { ayrıntılara yer vermeyen } \\
\text { anlatım }\end{array}$ & 1 & $\% 2,2$ & 1 & $\% 2,2$ \\
\hline ayrıntıya dikkat çekmeme & 1 & $\% 2,2$ & 1 & $\% 2,2$ \\
\hline duygusal olmayan anlatım & - & $\% 0$ & 2 & $\% 4,4$ \\
\hline $\begin{array}{l}\text { onaylanma gereksinimi } \\
\text { duymayan anlatım }\end{array}$ & - & $\% 0$ & 2 & $\% 4,4$ \\
\hline $\begin{array}{l}\text { içeriğin kadın beğenisini } \\
\text { yansıtması }\end{array}$ & 1 & $\% 2,2$ & - & $\% 0$ \\
\hline kibar dil kullanımı & - & $\% 0$ & 1 & $\% 2,2$ \\
\hline $\begin{array}{l}\text { samimi ve sicak olmayan } \\
\text { anlatım }\end{array}$ & 1 & $\% 2,2$ & - & $\% 0$ \\
\hline
\end{tabular}




\subsection{Erkek Yazara (2. Metin) Yönelik Bulgular ve Değerlendirmeler}

Erkek yazara ilişkin tespitlerdeki işlevler Tablo (8)'de dilbilgisel görünümleriyle birlikte verilmiştir. Katılımcıların ortaya koyduğu dilsel kanıtlar kutucuğunda katılımcıların metinden yaptı̆̆ı alıntılar tırnak içinde, metin hakkındaki yorumları ise tırnaksız olarak verilmiştir.

Tablo 8: Kadın katılımcılar tarafından 2. Metin'deki erkek yazarın cinsiyetine ilişkin tahminleri biçimlendiren kavramlar

\begin{tabular}{|c|c|c|}
\hline Kavram ve işlevler & Katılımcıların ortaya koyduğu dilsel kanıtlar & Sıklık \\
\hline erkeksi söylem & $\begin{array}{l}\text { eksiltili tümce kullanımı, "geçiniz", "fillm bu ya", kelimelerin } \\
\text { seçimi, çok fazla ünlem ve bağlaç kullanmamış, "yapılmış } \\
\text { büyük bir ayıp arkadaşlar", "arkadaşlar" }\end{array}$ & 11 \\
\hline duygusal anlatım & $\begin{array}{l}\text { “oturup ağlarsınız”, “duygulanmamanız mümkün değil”, } \\
\text { "yazar eksiltili tümceler kurmuş” }\end{array}$ & 8 \\
\hline duygusal olmayan anlatım & & 6 \\
\hline $\begin{array}{l}\text { duyguları belli etmeyen nesnel } \\
\text { anlatım }\end{array}$ & & 6 \\
\hline eleştirel dil & $\begin{array}{l}\text { "bundan dolayı", "büyük bir ayıp arkadaşlar", "orijinal bir } \\
\text { hikaye" }\end{array}$ & 5 \\
\hline sert anlatım & & 5 \\
\hline kadınsı söylem & $\begin{array}{l}\text { "geçiniz", "falan”, “oturup ağlarsınız", "duygulanmamanız } \\
\text { mümkün değil”, "karşılaşmışmış" ifadesindeki “-mışmış" } \\
\text { biçimindeki dedikodu eki, ayrıntılara dikkat çekilmiş }\end{array}$ & 4 \\
\hline kesin ifadelerle anlatım & & 4 \\
\hline $\begin{array}{l}\text { söylediklerini yumuşatma gereği } \\
\text { duymama }\end{array}$ & & 4 \\
\hline yalın, sade ve düz anlatım & & 3 \\
\hline iknaya ve ispata yönelik anlatım & & 3 \\
\hline sorgulayıcı bir dil kullanımı & "yazar uzun bir tümce kurmuş" & 2 \\
\hline somut anlatım & & 2 \\
\hline resmi bir dil kullanımı & & 2 \\
\hline öznel anlatım & & 2 \\
\hline samimi ve sicak anlatım & & 2 \\
\hline kibar dil kullanımı & & 1 \\
\hline edebî dil & & 1 \\
\hline $\begin{array}{l}\text { onaylanma gereksinimi } \\
\text { duymayan anlatim }\end{array}$ & & 1 \\
\hline empati kurabilme & & 1 \\
\hline açıklayıcı anlatım & & 1 \\
\hline betimleyici bir dil kullanımı & & 1 \\
\hline ayrıntıya dikkat çekme & & 1 \\
\hline ayrıntılı anlatım & & 1 \\
\hline
\end{tabular}


Tablo (8)'de kadın katılımcıların ortaya koyduğu kavram ve işlevler ile dilsel kanıtlar 2. Metin'in yazarının yüksek oranda doğru tahmin edildiğini göstermektedir. En fazla sıklığa sahip işlev erkeksi söylem (11 kez dile getirilmiş) olduğu gibi en fazla kanıt da yine bu işlev için ortaya konmuştur. Onu duygusal anlatım, duygusal olmayan anlatım, duyguları belli etmeyen nesnel anlatım, eleştirel dil, sert anlatım işlevleri takip etmiştir. Buna karşın erkeksi söylemden sonra en fazla sıklığı alan işlevin duygusal anlatım olması 2. Metnin yazarının 1. Metnin yazarına göre tahmin edilme oranının daha düşük olduğunu göstermektedir. Kadın katılımcılar kadın yazarı erkek yazardan daha fazla işlev ve dilbilgisel kanıtla tahmin edebilmişlerdir. Aşağıda verilecek sıklık oranları Tablo (4) ile karşılaştırıldığında bu durumu daha iyi açıklayacaktır. Tablo (9), Tablo (8)'de ortaya çıkan işlev dağılımlarının sıklığını kadın-erkek yazar değiştirgeni bağlamında görmek açısından daha net bir resim sunmaktadır. Tablo (9)'da yer alan erkeksi söylem, duygusal olmayan anlatım, duyguları belli etmeyen nesnel anlatım, eleştirel dil, sert anlatım, kesin ifadelerle anlatım, söylediklerini yumuşatma gereği duymama, yalın, sade ve düz anlatım, iknaya ve ispata yönelik anlatım, sorgulayıcı bir dil kullanımı, somut anlatım, onaylama gereksinimi duymayan anlatım biçiminde sıralanan işlevler, katılımcılara göre metnin erkek bir yazara ait olduğunu kanıtlamaktadır. Erkek yanıtı için öne sürülen işlevlerin sıklık sayısı 52 iken kadın yanıtı için öne sürülen işlevlerin sıklık sayısı 18'dir.

Tablo 9: Kadın katılımcılar açısından 2. Metin (erkek yazar) için erkek ve kadın yanıtını destekleyen işlevleri kümelendirerek yazar cinsiyeti açısından sıklık sayılarını değerlendirme

\begin{tabular}{|c|c|c|c|}
\hline & & İşlevler ve sıklık sayıları & Toplam \\
\hline \multirow{12}{*}{$\begin{array}{l}\text { erkek yanıtı için öne sürülen } \\
\text { işlevler }\end{array}$} & 1 & erkeksi söylem: 11 & \multirow[t]{12}{*}{52} \\
\hline & 2 & duygusal olmayan anlatım: 6 & \\
\hline & 3 & duyguları belli etmeyen nesnel anlatım: 6 & \\
\hline & 4 & eleştirel dil: 5 & \\
\hline & 5 & sert anlatım: 5 & \\
\hline & 6 & kesin ifadelerle anlatım: 4 & \\
\hline & 7 & söylediklerini yumuşatma gereği duymama: 4 & \\
\hline & 8 & yalın, sade ve düz anlatım: 3 & \\
\hline & 9 & iknaya ve ispata yönelik anlatım: 3 & \\
\hline & 10 & sorgulayıcı bir dil kullanımı: 2 & \\
\hline & 11 & somut anlatım: 2 & \\
\hline & 12 & onaylama gereksinimi duymayan anlatım: 1 & \\
\hline
\end{tabular}




\begin{tabular}{|c|c|c|c|}
\hline \multirow{6}{*}{$\begin{array}{l}\text { kadın yanıtı için öne sürülen } \\
\text { işlevler }\end{array}$} & 1 & duygusal anlatım: 8 & \multirow[t]{7}{*}{18} \\
\hline & 2 & kadınsı söylem: 4 & \\
\hline & 3 & öznel anlatım: 2 & \\
\hline & 4 & samimi ve sıcak anlatım: 2 & \\
\hline & 5 & kibar dil kullanımı: 1 & \\
\hline & 6 & ayrıntılı anlatım: 1 & \\
\hline öne sürülen toplam işlev sayısı & 18 & & \\
\hline
\end{tabular}

Erkek katılımcıların erkek yazara ilişkin ortaya koyduğu işlevler Tablo (10)'da gösterilmiştir. Tabloda bulunan Katılımcıların ortaya koyduğu dilsel kanıtlar kutucuğunda katılımcıların metinden yaptığı alıntılar tırnak işareti içinde, metin hakkındaki yorumları ise tırnaksız verilmiştir.

Tablo 10: Erkek katılımcılar tarafından 2. Metin'deki erkek yazarın cinsiyetine ilişkin tahminleri biçimlendiren kavramlar

\begin{tabular}{|c|c|c|}
\hline Kavram ve işlevler & Katılımcıların ortaya koyduğu dilsel kanıtlar & Sıklık \\
\hline erkeksi söylem & $\begin{array}{l}\text { eksiltili tümce (üç noktayla biten tümce) kullanımı, "bırakın } \\
\text { filmi, yapımcıyı falan", "karşılaşmış" ibaresindeki -mışmış } \\
\text { kullanımı, "film bu ya", "orijinal bir hikaye", "büyük bir } \\
\text { ayıp arkadaşlar", "duygulanmamanız mümkün değil" }\end{array}$ & 8 \\
\hline kadınsı söylem & $\begin{array}{l}\text { eksiltili tümce (üç noktayla biten tümce) kullanımı, } \\
\text { "geçiniz", "fillm bu ya", "karşılaşmış" ibaresindeki -mışmış } \\
\text { kullanımı, 3. çoğul kullanımı, seslenme biçimi, sözdizimsel } \\
\text { yapı }\end{array}$ & 7 \\
\hline duygusal anlatım & “geçiniz”, “film bu ya”, sözcük seçimi & 7 \\
\hline duygusal olmayan anlatım & & 5 \\
\hline sert anlatım & & 4 \\
\hline duyguları belli etmeyen nesnel anlatım & & 3 \\
\hline yalın, sade ve düz anlatım & & 3 \\
\hline iknaya ve ispata yönelik anlatım & & 3 \\
\hline abartılı olmayan duygu aktarımı & & 2 \\
\hline resmi bir dil kullanımı & & 2 \\
\hline eleştirel dil & & 2 \\
\hline ayrintılı anlatım & & 2 \\
\hline samimi ve sicak anlatım & & 2 \\
\hline argo kullanımı & "birakın", "uyduruk" & 1 \\
\hline kesin ifadelerle anlatım & "geçiniz" & 1 \\
\hline içeriğin erkek beğenisini yansıtması & konudan dolayı & 1 \\
\hline yumuşak anlatım & "ayıp arkadaşlar" & 1 \\
\hline
\end{tabular}




\begin{tabular}{|l|l|l|}
\hline kaba dil kullanımı & & 1 \\
\hline resmi olmayan dil kullanımı & & 1 \\
\hline ayrıntılara yer vermeyen anlatım & & 1 \\
\hline açıklayıcı anlatım & & 1 \\
\hline heyecan ve coşku içermeyen anlatım & & 1 \\
\hline somut anlatım & & 1 \\
\hline
\end{tabular}

Tablo (10)'da erkeksi söylem ile kadınsı söylem arasında sıklık açısından fark 1'dir. Bu sonuç erkek katılımcıların 2. Metin'deki erkek yazarı doğru tahmin edemedikleri anlamına gelmez. Şöyle ki yazarın erkek olduğuna ilişkin öne sürülen işlevlerle kadın olduğunu ileri süren işlevler sıklık açısından toplandığında 2. Metnin açık bir farkla erkek olarak varsayıldığ anlaşılmaktadır. Tablo (10)'da erkek katılımcıların ortaya koyduğu kavram ve işlevler ile dilsel kanıtlar 2. Metin'in yazarının yüksek oranda doğru tahmin edildiğini göstermektedir. En fazla sıklığa sahip işlev erkeksi söylem (8 kez dile getirilmiş) olduğu gibi en fazla kanıt da yine bu işlev için ortaya konmuştur. Ancak, kadınsı söylem işlevi için ortaya konulan kanıtlardan yalnızca 1 fazlasıdır. Yalnızca bu iki işlev (erkeksi söylem ve kadınsı söylem) açısından bakıldı̆̆ında metnin yazarının katılımcılar tarafından sezinlenemediği söylenebilirdi. Erkeksi söylemden başka ortaya konan duygusal olmayan anlatım, sert anlatım, duyguları belli etmeyen nesnel anlatım gibi işlevler bir arada düşünüldüğünde erkek katılımcıların metnin yazarını doğru tahmin edebildiği söylenebilir. Onu duygusal anlatımdan sonra takip eden duygusal olmayan anlatım, sert anlatım, duyguları belli etmeyen nesnel anlatım, yalın, sade ve düz anlatım gibi işlevler yine erkek katılımcılar tarafından metnin yazarının erkek olduğunu gösteren işlevler olarak belirtilmiştir. Buna karşın erkeksi söylemden sonra en fazla sıklığı alan işlevin kadınsı söylem ile duygusal anlatım olması 2. Metnin yazarının 1. Metnin yazarına göre tahmin edilme oranının daha düşük olduğunu göstermektedir. Aşağıda verilecek sıklık oranları da bu durumu daha iyi açıklayacaktır. Tablo (11), Tablo (10)'da ortaya çıkan işlev dağılımlarının sıklığını kadın-erkek yazar değiştirgeni bağlamında görmek açısından daha net bir resim sunmaktadır. Tablo (11)'de yer alan erkeksi söylem, duygusal olmayan anlatım, sert anlatım, duyguları belli etmeyen nesnel anlatım, yalın, sade ve düz anlatım, iknaya ve ispata yönelik anlatım, abartılı olmayan duygu aktarımı, resmi bir dil kullanımı, eleştirel dil, argo kullanımı, kesin ifadelerle anlatım, içeriğin erkek beğenisini yansıtması, kaba dil kullanımı, heyecan ve coşku içermeyen anlatım, sert anlatım, somut anlatım biçiminde sıralanan işlevler, katılımcılara göre metnin erkek bir yazara ait olduğunu kanıtlamaktadır. Erkek yanıtı için öne sürülen işlevlerin sıklık sayısı 38 iken kadın yanıtı için öne sürülen işlevlerin sıklık sayısı 19’dur. 
Tablo 11: Erkek katılımcılar açısından 2. Metin için erkek ve kadın yanıtını destekleyen işlevleri kümelendirerek yazar cinsiyeti açısından sıklık sayılarını değerlendirme

\begin{tabular}{|c|c|c|c|}
\hline & & İşlevler ve sıklık sayıları & Toplam \\
\hline \multirow{16}{*}{$\begin{array}{l}\text { erkek yanıtı için öne } \\
\text { sürülen işlevler }\end{array}$} & 1 & erkeksi söylem: 8 & \multirow[t]{16}{*}{38} \\
\hline & 2 & duygusal olmayan anlatım: 5 & \\
\hline & 3 & sert anlatım: 3 & \\
\hline & 4 & duyguları belli etmeyen nesnel anlatım: 3 & \\
\hline & 5 & yalın, sade ve düz anlatım: 3 & \\
\hline & 6 & iknaya ve ispata yönelik anlatım: 3 & \\
\hline & 7 & abartılı olmayan duygu aktarımı: 2 & \\
\hline & 8 & resmi bir dil kullanımı: 2 & \\
\hline & 9 & eleştirel dil: 2 & \\
\hline & 10 & argo kullanımı: 1 & \\
\hline & 11 & kesin ifadelerle anlatım: 1 & \\
\hline & 12 & içeriğin erkek beğenisini yansıtması: 1 & \\
\hline & 13 & kaba dil kullanımı: 1 & \\
\hline & 14 & heyecan ve coşku içermeyen anlatım: 1 & \\
\hline & 15 & sert anlatım: 1 & \\
\hline & 16 & somut anlatım: 1 & \\
\hline \multirow{5}{*}{$\begin{array}{l}\text { kadın yanıtı için öne } \\
\text { sürülen işlevler }\end{array}$} & 1 & kadınsı söylem: 7 & \multirow[t]{6}{*}{19} \\
\hline & 2 & duygusal anlatım: 7 & \\
\hline & 3 & ayrıntılı anlatım: 2 & \\
\hline & 4 & samimi ve sıcak anlatım: 2 & \\
\hline & 5 & yumuşak anlatım: 1 & \\
\hline $\begin{array}{l}\text { öne sürülen toplam işlev } \\
\text { sayısı }\end{array}$ & 21 & & \\
\hline
\end{tabular}

Erkek yanıtı için öne sürülen işlevler toplandığında erkek katılımcıların 2. Metin yazarının cinsiyetini doğru tahmin ettikleri ve yorumladıkları söylenebilir. Erkek yanıtı için toplam işlev sıklığı 38 iken kadın yanıtı için toplam işlev sayısı 19'dur. Ancak, 2. Metin üzerine kadın ve erkek katılımcıların tahminleri, ortaya koydukları sıklık değerleri açısından değerlendirildiğinde kadınların erkeklere göre metin yazarının cinsiyetini daha doğru tahmin ettikleri anlaşılmaktadır. Tablo (9) ile Tablo (11)'de yer alan değerler yeniden karşılaştırıldığında bu daha iyi anlaşılacaktır. Tablo (9)’da görüldüğü gibi kadın katılımcılar 2. Metnin yazarını işlevlere yaptıkları 52 gönderimle, erkek katılımcılar ise (bk. Tablo (11)) işlevlere yaptıkları 38 gönderimle metnin yazarını doğru tahmin etmişlerdir. Kadın katılımcıların bir diğer farkı ise tahminlerini daha çok işleve bulunarak belirtmiş olmalarıdır. 52+10=78 (bk. Tablo (9)). Erkek katılımcılar ise işlevlere toplamda $57(38+19)$ gönderimde bulunmuşlardır. Buradan yola çıkarak kadınların metnin 
yazarına ilişkin tahminde bulunurken daha ayrıntılı düşündüklerini söylemek mümkündür. Buna karşın, erkekler 2. Metnin doğrudan yazarın cinsiyetine yönelik tahminlerinde toplam 21 işlev ortaya koymuşken kadınlar 18 işlev ortaya koymuşlardır (krş. Tablo (9) ile Tablo (11)). Oysaki kadınlar 1. Metnin doğrudan yazarın cinsiyetine yönelik tahminlerinde toplam 18 işlev ortaya koymuşken erkekler 15 işlev ortaya koymuşlardı (krş. Tablo (4) ile Tablo (6)).

2. Metin' deki yazar cinsiyetine ilişkin tahminleri biçimlendiren kavramların cinsiyete göre dağılımı aşağıdaki tabloda verilmiştir. Tablodaki kadınların sıklık yüzdesi toplam kadın katılımcı sayısı olan 45, erkeklerin yüzdesi ise toplam erkek sayısı olan 45 üzerinden hesaplanmıştır.

Tablo 12: Erkek yazarın cinsiyetine ilişkin tahminleri biçimlendiren kavramların katılımcıların cinsiyetine göre sıklık dağ 11 lımı

\begin{tabular}{|c|c|c|c|c|}
\hline \multirow[b]{2}{*}{ Kavram ve ișlevler } & \multicolumn{2}{|c|}{ Kadınlar } & \multicolumn{2}{|c|}{ Erkekler } \\
\hline & Sıklık & Sıklık Yüzdesi & Sıklık & Sıklık Yüzdesi \\
\hline erkeksi söylem & 11 & $\% 24,44$ & 8 & $\% 17,17$ \\
\hline duygusal anlatım & 8 & $\% 17,77$ & 7 & $\% 15,55$ \\
\hline duygusal olmayan anlatım & 6 & $\% 13,3$ & 5 & $\% 11,11$ \\
\hline kadınsı söylem & 4 & $\% 8,8$ & 7 & $\% 15,55$ \\
\hline sert anlatım & 5 & $\% 11,11$ & 4 & $\% 8,8$ \\
\hline $\begin{array}{l}\text { duyguları belli etmeyen nesnel } \\
\text { anlatım }\end{array}$ & 6 & $\% 13,3$ & 3 & $\% 6,6$ \\
\hline eleştirel dil & 5 & $\% 11,11$ & 2 & $\% 4,4$ \\
\hline yalın, sade ve düz anlatım & 3 & $\% 6,6$ & 3 & $\% 6,6$ \\
\hline iknaya ve ispata yönelik anlatım & 3 & $\% 6,6$ & 3 & $\% 6,6$ \\
\hline kesin ifadelerle anlatım & 4 & $\% 8,8$ & 1 & $\% 2,2$ \\
\hline resmi bir dil kullanımı & 2 & $\% 4,4$ & 2 & $\% 4,4$ \\
\hline $\begin{array}{l}\text { söylediklerini yumuşatma gereği } \\
\text { duymama }\end{array}$ & 4 & $\% 8,8$ & - & $\% 0$ \\
\hline samimi ve sicak anlatım & 2 & $\% 4,4$ & 2 & $\% 4,4$ \\
\hline ayrıntılı anlatım & 1 & $\% 2,2$ & 2 & $\% 4,4$ \\
\hline sorgulayıcı bir dil kullanımı & 2 & $\% 4,4$ & - & $\% 0$ \\
\hline öznel anlatım & 2 & $\% 4,4$ & - & $\% 0$ \\
\hline açıklayıcı anlatım & 1 & $\% 2,2$ & 1 & $\% 2,2$ \\
\hline abartılı olmayan duygu aktarımı & - & $\% 0$ & 2 & $\% 4,4$ \\
\hline kibar dil kullanımı & 1 & $\% 2,2$ & - & $\% 0$ \\
\hline edebî dil & 1 & $\% 2,2$ & - & $\% 0$ \\
\hline $\begin{array}{l}\text { onaylanma gereksinimi } \\
\text { duymayan anlatım }\end{array}$ & 1 & $\% 2,2$ & - & $\% 0$ \\
\hline empati kurabilme & 1 & $\% 2,2$ & - & $\% 0$ \\
\hline betimleyici dil kullanımı & 1 & $\% 2,2$ & - & $\% 0$ \\
\hline
\end{tabular}




\begin{tabular}{|l|c|c|c|c|}
\hline ayrıntıya dikkat çekme & 1 & $\% 2,2$ & - & $\% 0$ \\
\hline argo kullanımı & - & $\% 0$ & 1 & $\% 2,2$ \\
\hline $\begin{array}{l}\text { içeriğin erkek beğenisini } \\
\text { yansıtması }\end{array}$ & - & $\% 0$ & 1 & $\% 2,2$ \\
\hline yumuşak anlatım & - & $\% 0$ & 1 & $\% 2,2$ \\
\hline kaba dil kullanımı & - & $\% 0$ & 1 & $\% 2,2$ \\
\hline resmi olmayan dil kullanımı & - & $\% 0$ & 1 & $\% 2,2$ \\
\hline ayrıntılara yer vermeyen anlatım & - & $\% 0$ & 1 & $\% 2,2$ \\
\hline $\begin{array}{l}\text { heyecan ve coşku içermeyen } \\
\text { anlatım }\end{array}$ & - & $\% 0$ & 1 & $\% 2,2$ \\
\hline somut anlatım & - & & & $\%$ \\
\hline
\end{tabular}

\subsection{Katılımcıların Sezgisel Tahminleri}

Farklı yaş gruplarından erkek ve kadınların kendilerine verilen 1. Metin (kadın yazar) ve 2. Metin'e (erkek yazar) ilişkin yazar cinsiyetine ilişkin tahminlerini biçimlendiren temel kavram ve işlevler dışında sezgiler de söz konusu olmuştur. Katılımcıların kanıt sunmadan ortaya koydukları sezgisel tahminler "Nedenini bilmiyorum ama bu metni bir kadın yazmış olmalı.”, "Bence bunu bir erkek yazmıştır” gibi ifadelerle aktarılmıştır. Buna göre, Tablo (4)’te yaş grubu ve cinsiyete göre metnin yazarlarını sezgisel olarak bilenlerin sayısı verilmiştir.

Tablo 13: Metinlerin yazar cinsiyetini sezgisel olarak doğru bilen kadın ve erkek katılımcılar

\begin{tabular}{|l|c|c|c|c|}
\hline & \multicolumn{2}{|c|}{ kadın } & \multicolumn{2}{c|}{ erkek } \\
\hline & 1. Metin & 2. Metin & 1. Metin & 2. Metin \\
\hline 15-18 yaş arası & - & - & - & - \\
\hline 19-25 yaş arası & - & 1 & 2 & 1 \\
\hline 35 yaş ve sonrası & - & - & - & - \\
\hline
\end{tabular}

Tablo (13)'ten anlaşıldığg üzere metinlerin yazarlarını sezgisel olarak tahmin etmede erkekler 1 sayı farkla ön sırada yer almıştır. Bu anlamda, cinsiyetler arasındaki farklılığı daha sağlıklı sonuçlar açısından belirlemek için çok daha fazla katılımcıdan bilgi toplamak gerekmektedir.

Sezgisel olarak metinlerin yazar cinsiyetini sezgisel olarak yanlış bilen kadın ve erkekler açısından da bakılabilir. 19-25 arası yaş gurubunda 1 kadın katılımcı 1. Metnin erkek bir yazara ait olduğunu söyleyerek yanlış bir tahminde bulunmuştur. 19-25 arası yaş gurubunda 1 kadın katılımcı 2. Metnin kadın bir yazara ait olduğunu söyleyerek yanlış bir tahminde bulunmuştur. 19-25 arası yaş grubunda 1 erkek katılımcı 1. Metnin erkek bir yazara ait olduğunu söyleyerek yanlış bir tahminde bulunmuştur. 19-25 arası yaş gurubunda 1 erkek katılımcı 2. Metnin kadın bir yazara ait olduğunu söyleyerek yanlış bir tahminde bulunmuştur. Bu sonuçların toplu gösterimi Tablo (14)'te verilmiştir. 
Tablo 14: Metinlerin yazar cinsiyetini sezgisel olarak yanlış bilen kadın ve erkek katılımcılar

\begin{tabular}{|l|c|c|c|c|}
\hline & \multicolumn{2}{|c|}{ kadın } & \multicolumn{2}{c|}{ erkek } \\
\hline & $\mathbf{1 .}$ Metin & 2. Metin & 1. Metin & 2. Metin \\
\hline 15-18 yaş aras1 & - & - & - & - \\
\hline $19-25$ yaş aras1 & 1 & 1 & 1 & 1 \\
\hline 35 yaş ve sonras1 & - & - & - & - \\
\hline
\end{tabular}

Sezgisel tahminlerin sayısı çok az olduğundan cinsiyet değişkeni açısından anlamlı bir fark ortaya çıkmamaktadır.

\subsection{Metin Yazarı Tahmininin Yaş ve Cinsiyete Göre Sayısal Dağılımı}

$\mathrm{Bu}$ bölümde, erkek ve kadın katılımcıların yazılı metinlerdeki yazarın cinsiyetini tahmin hususunda sayısal verilere dayalı olarak bir genel görünüm ortaya konmaya çalışılmıştır.

Tablo (15)'ten anlaşıldığı üzere metin yazarını tahmin etme noktasında erkek ve kadın katılımcılar arasında anlamlı olabilecek sayısal bir fark bulunmamaktadır.

Tablo 15: Metin yazarı tahmininin yaş ve cinsiyete göre sayısal dağılımı

\begin{tabular}{|c|c|c|c|c|c|c|c|c|}
\hline & \multicolumn{4}{|c|}{ Kadın } & \multicolumn{4}{|c|}{ Erkek } \\
\hline & \multicolumn{2}{|c|}{ 1. Metin } & \multicolumn{2}{|c|}{ 2. Metin } & \multicolumn{2}{|c|}{ 1. Metin } & \multicolumn{2}{|c|}{ 2. Metin } \\
\hline & Doğru & Yanlış & Doğru & Yanlış & Doğru & Yanlış & Doğru & Yanlış \\
\hline $15-18$ yaş arası & 9 & 6 & 7 & 8 & 11 & 4 & 8 & 7 \\
\hline $19-25$ yaş arası & 13 & 2 & 12 & 3 & 11 & 4 & 11 & 4 \\
\hline $\begin{array}{l}35 \text { yaş ve } \\
\text { sonrası }\end{array}$ & 13 & 2 & 10 & 5 & 15 & 0 & 11 & 4 \\
\hline Metne göre: & 35 & 10 & 29 & 16 & 37 & 8 & 30 & 15 \\
\hline Cinsiyete göre: & \multicolumn{4}{|c|}{ kadınlarda doğru: 64 yanlış: 26} & \multicolumn{4}{|c|}{ erkeklerde doğru: 67 yanlış: 23} \\
\hline Genel Toplam: & \multicolumn{8}{|c|}{ cinsiyet göz ardı edildiğinde genel doğru: 131 genel yanlış: 49} \\
\hline
\end{tabular}

Tablo (16)'dan yola çıkarak kadınlarda 1. Metin'e ait doğru tespitlerin en fazla 19-25 ile 35 yaş ve sonrası yaş grubunda eşit olarak paylaşıldığı görülmüştür. 15-18 yaş arası, doğru tespitin en az olduğu yaş grubu olmuştur.

Tablo 16: Kadınlarda yaş grubu açısından 1. Metin'in yazarına ilişkin doğru tespit sayısı

\begin{tabular}{|l|c|c|}
\hline & Kadınlar Yaş Grubu & Doğru Sayısı \\
\hline 1. & $15-18$ yaş arası & 9 \\
\hline 2. & $19-25$ yaş arası & 13 \\
\hline 3. & 35 yaş ve sonrası & 13 \\
\hline & & Toplam: 35 \\
\hline
\end{tabular}


Tablo (17)'den yola çıkarak erkeklerde 1. Metin'e ait doğru tespitlerin en fazla 35 yaş ve sonrası yaş grubunda fazla olduğu görülmektedir. 15-18 ile 19-25 yaş aralığı iki grubun doğru tahmini eşit çıkmıştır.

Tablo 17: Erkeklerde yaş grubu açısından 1. Metin'in yazarına iliş̧in doğru tespit sayısı

\begin{tabular}{|l|c|c|}
\hline & Erkekler Yaş Grubu & Doğru Sayısı \\
\hline 1. & $15-18$ yaş arası & 11 \\
\hline 2. & $19-25$ yaş arası & 11 \\
\hline 3. & 35 yaş ve sonrası & 15 \\
\hline & & Toplam: 37 \\
\hline
\end{tabular}

1. Metin söz konusu olduğunda kadınlar ve erkekler arasında şöylesi bir fark bulunmaktadır. Erkekler 2 sayı gibi küçük bir farkla (37’ye 35) kadınlardan daha fazla doğru tahminde bulunmuşlardır.

Tablo (18)'den yola çıkarak kadınlarda 2. Metin'e ait doğru tespitlerin en fazla 19-25 yaş arasında yer alan grupta olduğu görülmektedir.

Tablo 18: Kadınlarda yaş grubu açısından 2. Metin'in yazarına ilişkin doğru tespit sayısı

\begin{tabular}{|l|c|c|}
\hline & Kadınlar Yaş Grubu & Doğru Sayısı \\
\hline 1. & $15-18$ yaş arası & 7 \\
\hline 2. & $19-25$ yaş arası & 12 \\
\hline 3. & 35 yaş ve sonrası & 10 \\
\hline & & Toplam: 29 \\
\hline
\end{tabular}

Tablo (19)'dan yola çıkarak erkeklerde 2. Metin'e ait doğru tespitlerin 19-25 ile 35 yaş ve sonrası yaş grubunda eşit paylaşıldığ 1 görülmektedir. 15-18 yaş arası erkekler diğer yaş gruplarına oranla daha az doğru sayısına sahiptir.

Tablo 19: Erkeklerde yaş grubu açısından 2. Metin'in yazarına ilişkin doğru tespit sayısı

\begin{tabular}{|l|c|c|}
\hline & Erkekler Yaş Grubu & Doğru Sayısı \\
\hline 1. & $15-18$ yaş arası & 8 \\
\hline 2. & $19-25$ yaş arası & 11 \\
\hline 3. & 35 yaş ve sonrası & 11 \\
\hline & & Toplam: 30 \\
\hline
\end{tabular}

2. Metin söz konusu olduğunda kadınlar ve erkekler arasında şöyle bir fark bulunmaktadır. Erkekler 1 sayı gibi küçük bir farkla (30’a 29) kadınlardan daha fazla doğru tahminde bulunmuşlardır.

Hem 1. Metin hem de 2. Metin açısından kadın ve erkeklerin doğru bilme sayıları karşılaştırıldığında çok büyük bir fark bulunmadığı görülmektedir. Kadınların toplam doğru 
bilme sayısı 64 iken erkeklerinki 67'dir (bk. Tablo (15)). Toplam yanlışlar karşılaştırıldığında fark kadınlarda biraz daha fazladır. Kadınların yanlış sayısı 26 iken erkeklerinki 23'tür. Bu sonuçlar erkeklerin tahminlerinde daha isabetli olduklarını göstermektedir. Buna karşın, bütün bu doğru-yanlış sayıları açısından cinsiyet değişkenine göre genel bir yorum yapıldığında erkek ve kadınlar arasında anlamlı olacak düzeyde bir fark olmadığı anlaşılmıştır. Genel resimde ortaya çıkan bir diğer bulgu ise 15-18 yaş arasının metin yazarlarının cinsiyetini tahmin etmek noktasında daha zayıf kalmalarıdır. Cinsiyet ayrımı yapmadan katılımcıların doğru bilme sayıları Tablo (20)'de gösterilmiştir.

Tablo 20: Erkek ve kadınlarda yaş grubu açısından 1. Metin ve 2. Metin'in yazarına ilişkin doğru tespit siralamas1

\begin{tabular}{|l|c|c|}
\hline & Erkek ve Kadınlar Yaş Grubu & Toplam Doğru Sayısı \\
\hline 1. & 35 yaş ve sonrası & 49 \\
\hline 2. & $19-25$ yaş arası & 47 \\
\hline 3. & $15-18$ yaş arası & 35 \\
\hline
\end{tabular}

Tablo (20)'ye göre metin cinsiyeti üzerine en doğru tahmini yapan yaş grubu 35 yaş ve üzerinde yer alan yaş arasıdır. Onu 19-25 yaş arası takip etmiştir.

Cinsiyet ayrımı yapmadan katılımcıların yanlış tahmin etme sayıları Tablo (21)'de gösterilmiştir.

Tablo 21: Erkek ve kadınlarda yaş grubu açısından 1. Metin ve 2. Metin'in yazarına ilişsin yanlış tespit siralamas1

\begin{tabular}{|l|c|c|}
\hline & Erkek ve Kadınlar Yaş Grubu & Toplam Yanlış Sayısı \\
\hline 1. & 35 yaş ve sonrası & 11 \\
\hline 2. & $19-25$ yaş arası & 13 \\
\hline 3. & $15-18$ yaş arası & 25 \\
\hline
\end{tabular}

Tablo (21)'de ortaya çıkan sonuç Tablo (20) ile bakışımlı ve uyumludur. Sözgelimi, en fazla doğru tahminde bulunan 35 yaş ve üzeri yaş grubu aynı zamanda en az yanlış yapan grup olmuştur. Söz konusu bakışımlılık diğer yaş gruplarında da görülmüştür.

\section{Sonuç}

Bu çalışmadan ortaya çıkan sonuçlar ana yönleriyle birkaç maddede özetlenebilir.

(i) Doğru bilme sayısı açısından erkek ve kadın ayrımı yapmadan yaş grubuna göre bir değerlendirme yapıldığında şöyle bir sıralama ortaya çıkmıştır: 49 doğru ile 35 yaş ve üzeri yaş grubu birinci, 47 doğru ile 19-25 yaş arası ikinci, 35 doğru ile 15-18 yaş arası üçüncü olmuştur. Bu sonuçla bakışımlı ve uyumlu olarak, yanlış tahmin etme sayısı açısından erkek ve kadın ayrımı yapmadan yaş grubuna göre bir değerlendirme yapıldığında şöyle bir sıralama ortaya çıkmıştır: 25 yanlış ile 15-18 yaş grubu birinci, 13 yanlış ile 19-25 yaş arası ikinci, 11 yanlış 
ile 35 yaş ve üzeri yaş arası üçüncü olmuştur. Yaş grubuna göre ortaya çıkan bu bulgunun cinsiyet farklılı̆̆ını algılamak noktasında yaş ilerledikçe beynin daha iyi bir algılamaya sahip olmasıyla açıklanabilir. Ancak bu açıklamanın beyindilbilim çalışmalarıyla desteklenmesi ve kanıtlanması gerekmektedir.

(ii) Yazılı bir metinde açık bir cinsiyet kodlayıcı olmadığı durumlarda bile kadın ve erkek okuyucuların yazarın cinsiyetine ilişkin doğru yanıtlar verebildiği görülmüştür. Kadın ve erkekler cinsiyet algısını ortaya çıkaran dilsel birimleri bilişsel işlemlerle doğru tespit edebilmektedir.

(iii) Metin yazarlarının cinsiyetine ilişkin doğru tahminler, Türkçede dilbilgisel düzlemde baskın bir cinsiyet kodlayıcısı olmasa da dil kullanıcılarının sözlüksel ve çeşitli dilsel biçemlere dayalı olarak işlemledikleri sezgisel bir cinsiyet algısının (intuitive gender perception) varlığını göstermektedir. Bu da yazılı metne yansıyan cinsiyet biçemini algılamaya odaklı hem doğuştan gelen hem de çeşitli tecrübelere dayalı olarak geliştirilen bilişsel yetilerin olduğunu göstermektedir. Söz konusu cinsiyet algısı kadın ve erkek katılımcılar açısından karşılaştırıldığında kadın katılımcıların hem birinci hem de ikinci metinde yazarın cinsiyetine ilişkin daha doğru tahminler yapabildiği görülmüştür. Ancak, arada büyük oransal bir fark bulunmamaktadır. Ayrıca kadınlar erkeklere oranla daha çok işlev ortaya koymuşlardır.

(iv) Türkçedeki erillik dişillik açısından cinsiyet görünümü temel olarak sözlüksel düzeydedir. Katılımcıların belirlediği birçok işlev sözcüklerden yola çıkılarak ortaya konmuştur.

(v) Duygusal anlatım, heyecanlı ve coşkulu anlatım, abartılı duygu aktarımı, samimi ve sıcak anlatım, öznel anlatım, anlatımda duygusal çeşitlilik, hızlı duygu değişimi, ayrıntılı anlatım gibi işlevler kadınsı söylem kümesini oluşturmaktadır.

(vi) Duygusal olmayan anlatım, duyguları belli etmeyen nesnel anlatım, yalın, sade ve düz anlatım, iknaya ve ispata yönelik anlatım, abartılı olmayan duygu aktarımı, resmi bir dil kullanımı, eleştirel dil, argo kullanımı, kesin ifadelerle anlatım, kaba dil kullanımı, heyecan ve coşku içermeyen anlatım, sert anlatım, somut anlatım gibi işlevler erkeksi söylem kümesini oluşturmaktadır.

(vii) Erkek yazara ait olan 2. Metin, kadın yazara ait olan 1. Metin'den daha az sıklık oranıyla doğru tahmin edilmiştir. Bunun en önemli göstergesi 2. Metin için kadınsı söylem ve duygusal anlatım işlevlerine kadın ve erkek katılımcılar tarafından fazlaca gönderimde bulunulmasıdır.

(viii) Tablo (22)'de görüldüğü üzere, kadınların işlevlere gönderim sayısı hem birinci hem de ikinci metinde daha yüksek. Buna karşın daha fazla işlev türü ortaya koymak açısından 1 . Metin'de kadınlar 2. Metin'de ise erkekler daha öndedir. Ancak bu, anlamlı olabilecek kadar yüksek bir oran değildir. 
Tablo 22: Erkek ve kadın katılımcılar tarafından yazar cinsiyeti tahmininde işlevlere yapılan gönderim sıklığı ve işlev türleri sayısı

\begin{tabular}{|l|c|c|c|c|}
\hline & \multicolumn{2}{|c|}{$\begin{array}{c}\text { yazar cinsiyeti tahmininde } \\
\text { işlevlere yapılan toplam gönderim } \\
\text { sıklığı }\end{array}$} & $\begin{array}{c}\text { yazar cinsiyeti tahmininde katılımcılar } \\
\text { tarafından ortaya konan işlev türü sayısı }\end{array}$ \\
\hline 1. Metin & Kadın & Erkek & Kadın & 15 \\
\hline 2. Metin & 78 & 68 & 18 & 21 \\
\hline
\end{tabular}

(ix) $\mathrm{Bu}$ çalışmada ortaya çıkan bir diğer bulgu ise 15-18 yaş arasının metin yazarlarının cinsiyetini tahmin etme noktasında diğer yaş gruplarına göre biraz daha zayıf kalmalarıdır. $\mathrm{Bu}$ da yaş değişkeninin metin yazarı cinsiyetini algılamada önemli olabileceğine ilişkin bir kanit olabilir.

(x) Genel bir sonuç olarak, yukarıda söz edilen farklar geçici olarak bir kenara bırakılacak olursa, kadın ve erkek katılımcılar arasında metnin cinsiyetini tahmin etmede büyük ölçekli (“anlamlı”) bir farkın bulunamadığı rahatlıkla söylenebilir.

Hakem Değerlendirmesi: Dış bağımsız.

Çıkar Çatışması: Yazarlar çıkar çatışması bildirmemiştir.

Finansal Destek: Yazarlar bu çalışma için finansal destek almadığını beyan etmiştir.

Peer-review: Externally peer-reviewed.

Conflict of Interest: The authors have no conflict of interest to declare.

Grant Support: The authors declared that this study has received no financial support.

\section{Kaynakça/References}

Aksan, D. (1977). Her Yönüyle Dil (Ana Çizgileriyle Dilbilim). Ankara: TDK.

Al Rousan ve diğ. (2011). Gender Differences in the Typographical Features Used in the Text Messaging of Young Jordanian Undergraduates. International Conference on Languages, Literature and Linguistics [IPEDR], Sayı 26. Singapore: IACSIT Press.

Aliefendioğlu, H. (1997). Konuşma Dilinde Cinsiyete Dayalı Farklılaşma: Kadın ve Erkek Dili. Antropoloji, Say1 13, s. 17-36.

Arman, A. (2018, 8 Mart). 8 Mart'ta Hürriyet’ten yeni bir devrim: Kadın düşmanı kelimeleri dilimizden kovuyoruz!!! Hürriyet. Erişim adresi: www.hurriyet.com.tr

Arman, A. (2018, 18 Mart). Çok da Şey etmemek Lazım! Hürriyet. Erişim adresi: www.hurriyet.com.tr

Baker, P. (2006). Using Corpora in Discourse Analysis. London, New York: Continuum.

Börekçi, M. ve Tercanoğlu, L. (1999). Türkçe ve İngilizce’de Dil ve Cins İlişkisi Üzerine Bir Deneme. A.Ü. Türkiyat Araştırmaları Enstitüsü Dergisi, Sayı 12, s. 31-52.

Cambridge Dictionary online (2018). Cambridge English Dictionary. Cambridge University Press. https:// dictionary.cambridge.org/dictionary/english/ (erişim tarihi: 26.03.2018).

Crystal, D. (2003). A Dictionary of Lingustics \& Phonetics. Oxford: Blackwell Publishing. 
Deborah, C ve Panović, I. (2014). Working with Written Discourse. London: SAGE Publications.

Doğan, E. (2011). Türkiye Türkçesinde Cinsiyet Kategorisinin İzleri. Uluslararası Sosyal Araştırmalar Dergisi, Cilt:4, Say1 17, s. 89-98.

Finch, G. (2000). The Linguistic Terms and Concepts. London: Mcmillan Press.

Howarth, D. (2000). Discourse. Buckingham UK: Open University Press.

Karaağaç, G. (2011). Bireysel İki Dillilik ve Toplumsal İki Dillilik. Türk Dili ve Edebiyatı Dergisi, Sayı 717, s. $222-228$.

Korkmaz, Z. (1992). Gramer Terimleri Sözlüğü. Ankara: TDK.

König, G. (1992). Dil ve Cins: Kadın ve Erkeklerin Dil Kullanımı. Dilbilim Araştırmaları 1992. Hitit Yayınevi, s. 26-36.

Mills, S. (1997). Discourse. London and New York: Routledge.

Önem, E. (2011). Bireysel Dil Kullanımını Etkileyen Etkenler. Dil Dergisi, Sayı 152, s. 57-67.

Renkema, J. (2004). Introduction to Discourse Studies. Amsterdam, Philadelphia: John Benjamins Publishing Company.

Schiffrin, D. (1996). Discourse Markers. Cambridge, New York: Cambridge University Press.

Sebzecioğlu, T. (2016). Dilbilim Kavramlarıyla Türkçe Dilbilgisi. İstanbul: Kesit Yayınları.

Sebzecioğlu, T. ve Coşgun Özgür, S. (2015). Cinsiyete Bağlı Argo Kullanımı Üzerine Bir Twitter Etiketi Örneklemi. Uluslararası Dil, Edebiyat ve Halkbilimi Araştırmaları Dergisi [TÜRÜK], Sayı 5, s. 75-93.

Semercioğlu, C. (2017). Oscar'a Bu Kadar Yakınken Ayla’ya Yapılanlara Bakın. Hürriyet. Erişim adresi: www.hurriyet.com.tr

Toklu, M. O. (2003). Dilbilime Giriş. Ankara: Akçă̆ Yayınları.

Vardar, B. ve diğ. (1998). Açıklamalı Dilbilim Terimleri Sözlüğ̈̈. Ankara-İstanbul-İzmir: ABC Kitabevi.

Y1lmaz, M. Y. (2018, 21 Ocak). Şu Erkekler Pek Yaman, Her Sözleri Bir Yalan. Hürriyet. Erişim adresi: www. hurriyet.com.tr 


\section{EKLER}

Ek 1: Kadın yazara ait 1. Metin ile ilgili veri toplama formu

Kadın 1 Erkek 1

Yaş aralığınız:

15-18 yaş arası 1

19-25 yaş arası 1

35 ve sonras 1

\section{METIN}

Aşağıdaki metni sizce hir lyadın mı yazmıştır yoksa bir erkek mi? Okuduktan sonra metnin altındaki kutucuğu tahmininizi $\backslash$ işareti ile kodlayınız.

Var ya... Mutlaka bu filmi izleyin! Hem güleceksiniz hem ăglayacaksınız. Hem şaşıracaksınız hem de "Çok fazla da şey etmemek lazım!” diyeceksiniz. Avuçlarım patlayıncaya kadar Tolga Karaçelik'i tebrik ediyorum. Biliyorum çok fazla da şey etmemek lazım ama elimde değil, ediyorum. Uzun zamandır böyle bir film izlememiştim, bana çok iyi geldi, inşallah size de öyle gelir. 'Kelebekler', genç yönetmen Tolga Karaçelik'in ödüllü filmi. ABD’nin bağımsız film festivali Sundance'te, Dünya Sineması dalında, Büyük Jüri Ödülü aldl. Adam hayatında üç film yapmış, üçü de dünya çapında ödüller almış. Filmini izleyip bu kadar beğenince, haliyle kendisini tanımak ve sizinle tanıştırmak istedim. Huzurlarınızda Tolga Karaçelik... Az evvel filmini izledim ve çarpıldım! Belli yerlerinde kahkahalar attım ama ağladiğım yerler de oldu. Finalde de dondum kaldım!

Metin yazarı bir kadın 1

1 Metin yazarı bir erkek 1

Yukarıdaki metnin neden bir kadına/erkeğe ait olduğunu düşündünüz? Bunu size hangi ek, hangi sözcük ya da hangi dilsel yapı düşündürttü? Nedenlerinizi metinden yola çıkarak aşağıdaki kutucuğa yazınız. 
Ek 2: Erkek yazara ait 2. Metin ile ilgili veri toplama formu

Kadın 1 Erkek 1

Yaş aralığınız:

15-18 yaş arası 1

19-25 yaş arası 1

35 ve sonrasi

\section{METIN}

Aşağıdaki metni sizce bir kadın mı yazmıştır yoksa bir erkek mi? Okuduktan sonra metnin altındaki kutucuğu tahmininizi \ işareti ile kodlayınız.

Neden en iddialı Oscar aday filmimiz diyorum önce onu söyleyeyim. Birincisi hikaye gerçek... Süleyman Onbaşı (Dilbirliği), Koreli kızı yolda karlar arasında bulmamış da, Türk taburunda karşılaşmışmış... Geçiniz... Film bu ya... Bundan dolayı "hikaye gerçek değil”" demek, bırakın filmi, yapımcıyı falan, bugün 92 yaşında olan Kore Gazimiz Süleyman Amca'ya yapılmış büyük bir ayıp arkadaşlar. Bu hikaye yüzde 100 gerçek... İkincisi bu hikayenin kahramanları yaşıyor... Tanıştım... Süleyman Amca'yla da, kızım dediği Koreli Kim 'le de (Ayla) buluşup konuştum. Oturup ağlarsınız... Süleyman Amca'nın üzerine titriyor bugün 67 yaşında olan Koreli Kim... Duygulanmamanız mümkün değil. Şimdi elinizde uyduruk senaryolardan bunalmış Amerikan sinemasının arayıp da bulamadı̆̆ bir hazine var: Orijinal bir hikaye... Olay gerçek, üstelik kahramanları da yaşıyor. Üçüncüsü savaş mağduru çocuklar gündemde... Ayla'nın anlattığı savaş mağduru çocuklar, bugün çok daha can yakıcı şekilde dünyanın gündeminde...

Metin yazarı bir kadın 1

Metin yazarı bir erkek 1

Yukarıdaki metnin neden bir kadına/erkeğe ait olduğunu düşündünüz? Bunu size hangi ek, hangi sözcük ya da hangi dilsel yapı düşündürttü? Nedenlerinizi metinden yola çıkarak aşağıdaki kutucuğa yazınız. 